\title{
Environmental Problems in Conservation of Cultural Heritage in Semarang
}

\author{
Ibnu Sodiq ${ }^{1}$, Ufi Saraswati ${ }^{2}$, Ardhi Prabowo ${ }^{3}$, Tsabit Azinar Ahmad ${ }^{4}$, Andy Suryadi ${ }^{5}$ \\ \{sejarah@mail.unnes.ac.id ${ }^{1}$, ufiratri@mail.unnes.ac.id ${ }^{2}$, ardhiprabowo@mail.unnes.ac.id ${ }^{3}$, \\ azinarahmad@mail.unnes.ac.id ${ }^{4}$, andypapasikembar@mail.unnes.ac.id $\left.{ }^{5}\right\}$ \\ 1,2,3,4,5 Universitas Negeri Semarang, Indonesia
}

\begin{abstract}
The municipality of Semarang as the capital of Central Java has been established since $1547 \mathrm{AD}$. Therefore, it has many historical heritages. Heritage has even existed since the Hindu Buddhist period. The legacy of the colonial period in Semarang is also abundant. One of the monumental is the old city area of Semarang. This historical legacy has a strategic meaning in strengthening people's identities. However, there are always problems found in preserving historical heritage in the city of Semarang. One of the issues that is often encountered is environmental problems. At some point, environmental problems are found, such as tidal flood, slum environment, to vandalism. This problem is an obstacle in preserving historical heritage in Semarang.
\end{abstract}

Keywords: Environmental Problem, Cultural Conservation, Cultural Heritage

\section{Introduction}

Semarang has various historical and cultural heritages stretch from the period of the ancient kingdom to the contemporary period. One of the most prominent is the heritage of the colonial period. This heritage has a strategic meaning in shaping the identity of cities and communities in Semarang. With the existence of cultural heritage, the town is expected to be able to absorb the values and meanings implicit in it. [1]

Semarang has 14 locations as cultural heritage areas (2) Petudungan, (3) Kampung Kulitan, (4) Kampung Batik, (5) Chinatowns, (6) Johar Market, (7) Kampung Melayu, (8) Kampung Kauman, (9) ) Tugu Muda, (10) Kampung Senjoyo , (11) Sam Poo Kong, (12) PJKA Kedungjati Housing, (13 Tombs of Sunan Terboyo, (14) Sekayu Village. These areas have high historical value, so they need to be preserved. [3]

However, there are several problems encountered in efforts to preserve cultural heritage in the city of Semarang. Kota Lama, which has great potential in tourism, is often in poor condition. Some corners look dirty and unkempt. [4] Besides, the Semarang City Regional Planning Agency also released that in the last ten years, more than 18 cultural heritage buildings have been lost.

The importance of conservation of historical relics in the city of Semarang has also been reviewed by Eko Punto Hendro who analyzed the protection of Kauman mosques which face the threat of damage. [5] Other researchers also recommend the need for conservation of cultural heritage areas in Semarang. [6]

One of the problems encountered in the preservation of the city so that culture in Semarang is an environmental problem. This paper specifically looks at how environmental issues are being faced in the preservation of cultural heritage areas in Semarang. 


\section{Research Method}

This research uses a qualitative approach. Observations were made at several points of the Semarang City cultural heritage area to collect primary research data. The main areas that were made views were the old city of Semarang, the Johar market area, and also the Senjoyo village area. This area is located in the northern part of Semarang. The secondary data from previous studies are also used

\section{Result and Discussion}

\subsection{Cultural Heritage Area in Semarang}

Semarang is a strategic port city on the north coast of Java. As the capital of the Central Java Province, Semarang is not only the center of government but also the center of industry, commerce, and education. Its area is $373.70 \mathrm{~km} 2$ [7]. Semarang city is unique because it is divided into two main areas. The upper part of Semarang, which has a hilly contour and the lower part of Semarang as a coastal city and a trade center.

Semarang is unique because it is the only hilly coastal city. Semarang's history stretched back to the time of the Islamic empire in the XV century. At first, Semarang was founded by Kyai Ageng Pandan Arang who became the first regent of Semarang until 1496 AD. [8] At that time, Semarang began to grow as a bustling port city and was visited by foreign traders. Chinese traders landed around the beginning of the 15th century, Portuguese and Dutch at the beginning of the 16th century, from Malaysia, India, Arabia, and Persia at the beginning of the 17th century. [9] [10]

Semarang has more than 328 cultural heritage buildings. The building includes buildings with social functions, such as schools, hospitals, post offices, stations. Then the religious buildings, including mosques, churches, and temples. Structures that function economically are office buildings, factories, warehouses, hotels, restaurants, and markets. Besides, there are also buildings in the form of dwellings, reservoirs, gates, and parks.

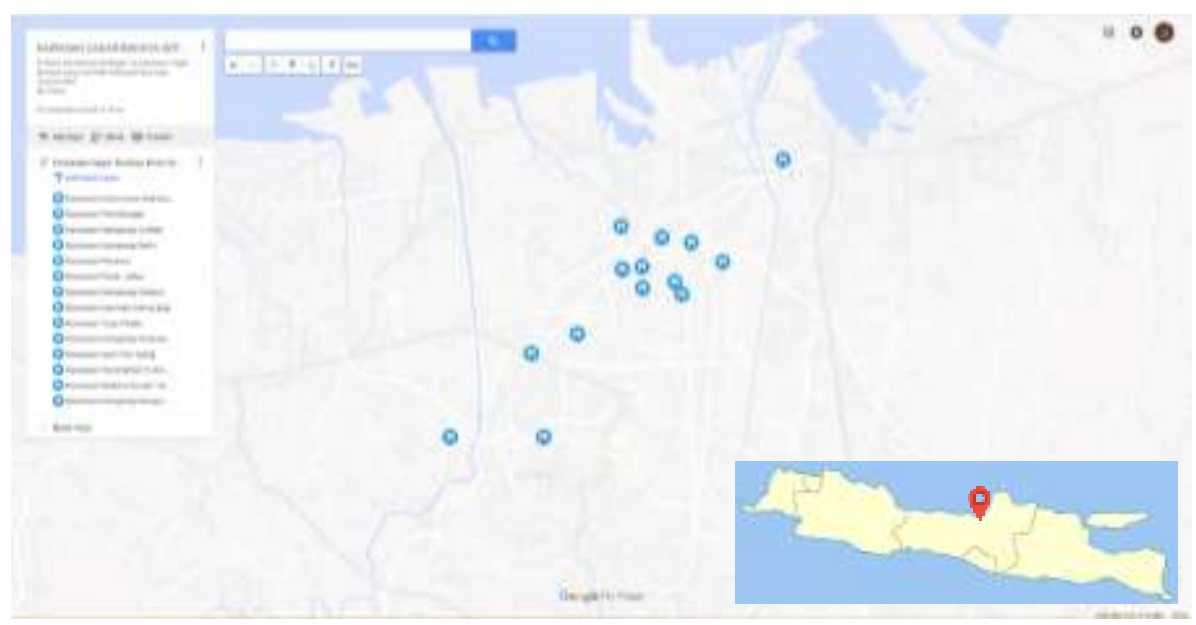

Fig. 1. Cultural Heritage Area in Semarang. 
The distribution of cultural heritage areas which are in several points shows the many historical heritages here. The number of cultural heritage areas owned is directly proportional to the potential and threat of damage. Including damage to the environment.

\subsection{Environmental Problems in the Conservation of Cultural Heritage}

Fourteen areas have been officially recorded in the government repository in Semarang City. All buildings are in a relatively good condition architecturally, but it has a potential threat that can change the original shape. It also has an impact on the damage and destruction of the building. The problem that is quite apparent is in the Old City of Semarang, and this region is on the north coast, which is quite close to the Java Sea. This condition makes flooding often occurs and makes several locations inundated. Inundation caused by seawater makes some buildings eroded and weathered, the weariness makes the structure of the building becomes fragile and loses its complexion. It also makes the streets in the Old City disorganized in the landscape, given that the tidal water is changing the structure of the land surface. In addition to threatening the essence, rob also has an impact on reducing the aesthetic value in the Old City of Semarang. More details can be seen in the following picture:

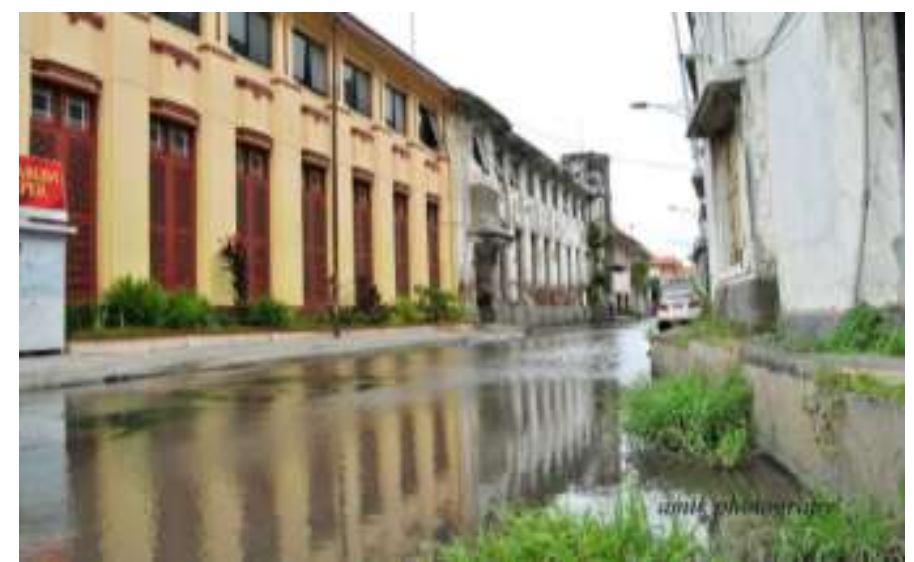

Fig. 2. Tidal flood in Old City of Semarang.

Besides flooding, another potential that can cause damage to cultural heritage is fire. In Semarang, there was a fire that devoured the historic buildings in the Jurnatan area, Pasar Johar. Pasar Johar Fire not only leaves bitter experiences of the traders there, but the public observers and historical activists also regret this. Pasar Johar is a monumental historical heritage in Semarang. It was the most significant market building in Southeast Asia in the 20th Century (Dutch East Indies Era). This market also a place for mixing various ethnic groups in Semarang City, namely Chinese, Javanese, Arabic, Madurese, and all ethnic groups. In the city of Semarang. 


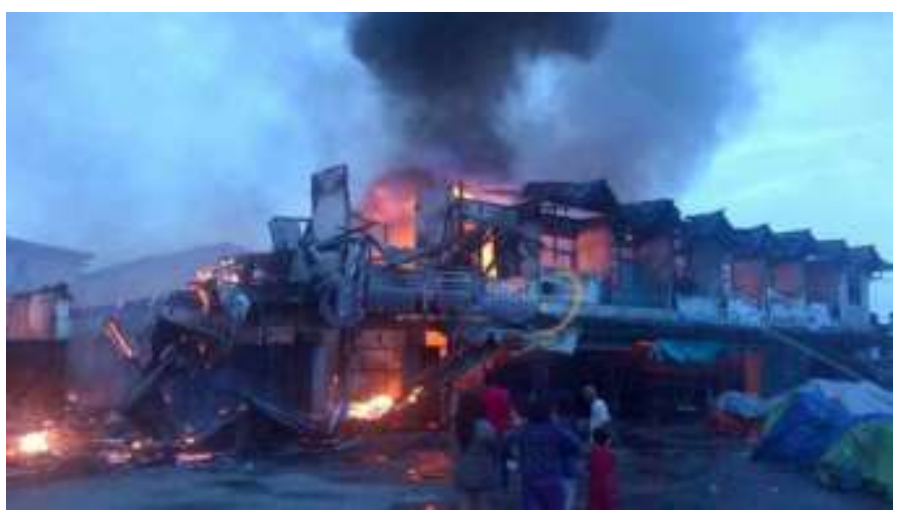

Fig. 3. Fire at Johar Market in 2015.

The burning of this building adds to the black record relating to the preservation of cultural heritage in Indonesian cities, which certainly cannot be adequately treated. Pasar Johar fires have used up all building construction and caused $90 \%$ damage to market buildings.

In addition to the two factors above, development is also a determinant in the continuity of historical heritage buildings. Aspects of growth in several areas in Semarang harm the existence of historical heritage buildings. This case can be found in Kampung Senjoyo, Chinatown, and Kulitan, some buildings in the region experienced a drastic change from its original form. It is influenced by capitalism, which consciously or unconsciously has changed the authentic way of historical heritage buildings. Urban development has long been a concern of many scientists in the world. Semarang City as a city that continues to experience growth and the magnitude of the influence of capital in city development. In Kampung Senjoyo, some buildings have drastic changes; even some buildings have been demolished and replaced with new buildings as shops and other business-style buildings. In Chinatown and Kulitan also experienced the same case. It can be observed in the image below:

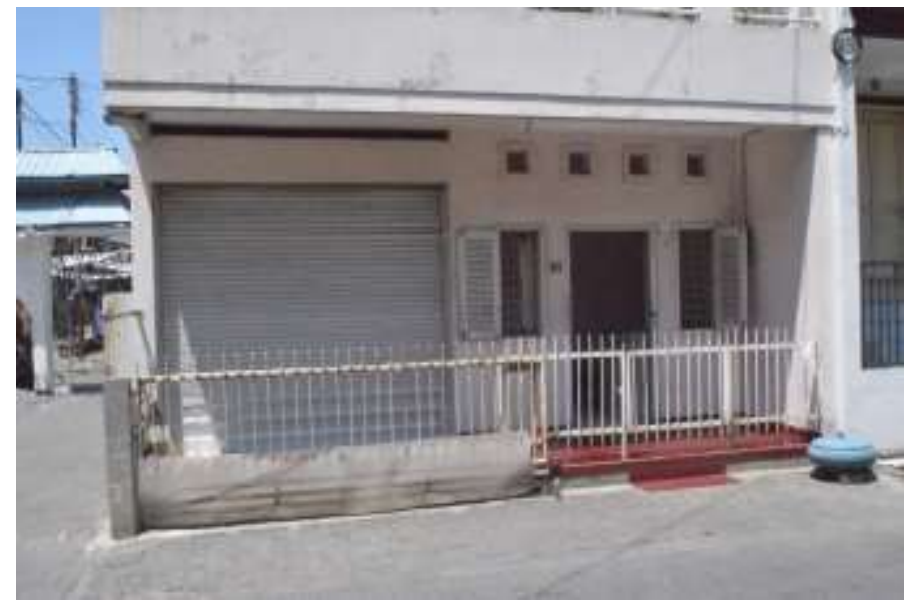

Fig. 4. The Buildings in Senjoyo Village were made into shops.

The other problems that have been identified are Puspitasari and Ramli are (1) lack of drainage treatment, (2) subsidence, (3) volume and traffic loads that exceed road capacity, (4) 
lack of clear circulation of motorized vehicles and pedestrians, ( 5) air pollution, (6) lack of greening, (7) waste problems, (8) lack of street furniture and improper placement, (9) lack of parking lots, (10) vandalism. [11].

\section{Conclusion}

Conservation of historical heritage has an essential meaning for strengthening people's identity and history. However, its preservation efforts face a series of problems. One of them is an environmental problem. In the city of Semarang, the most common environmental issues associated with the conservation of historical heritage are the problem of floods and tides. It changes and damage to the building structure. Besides, some fires destroyed monumental buildings, such as in Johar Market. Another environmental problem is waste and vandalism. It is an immediate task to be solved so that the history of Semarang continues to have existence.

This study recommends the importance of efforts to prevent environmental problems in the area of cultural heritage. One of them is by developing urban planning systems that are responsive to natural disasters. On the one hand, public awareness needs to be increased to participate in the preservation of cultural heritage areas in the city of Semarang.

\section{References}

[1] U. Tjandrasasmita, "Pelestarian Benda Cagar Budaya dan Pemanfaatannya bagi Pembangunan Bangsa," Suhuf, vol. 3, no. 1, pp. 131-143, 2010.

[2] E. P. Hendro, "Pelestarian kawasan konservasi di Kota Semarang," J. Konserv. Benda Cagar Budaya Borobudur, vol. 9, no. 1, pp. 17-28, 2015.

[3] "Peraturan Daerah Kota Semarang Nomor 14 Tahun 2011 tentang Rencana Tata Ruang Wilayah Kota Semarang Tahun 2011-2031,” 2011.

[4] E. H. Widiastuti, "Revitalisasi Benda Cagar Budaya di Kota Semarang," Fak. Pendidik. Ilmu Pengetah. Sos. IKIP Veteran Semarang, 2014.

[5] E. P. Hendro, "Konservasi Masjid Agung Kauman Semarang Sebagai Benda Cagar Budaya," Paramita Hist. Stud. J., vol. 21, no. 1, 2011.

[6] E. A. Rubiantoro, "Kajian Konservasi Bangunan Cagar Budaya Pada Koridor Jl. Kepodang Kota Semarang,” J. Riptek, vol. 12, no. 1, pp. 89-96, 2018.

[7] BPS, Semarang dalam Angka 2017. Semarang: Biro Pusat Statistik. 2018.

[8] A. Budiman, Semarang juwita: Semarang tempo doeloe, Semarang masa kini dalam rekaman kamera, vol. 1. Tanjung Sari, 1979.

[9] L. M. F. Purwanto, "Kota Kolonial Lama Semarang (Tinjauan Umum Sejarah Perkembangan Arsitektur Kota)," Dimens. (Journal Archit. Built Environ., vol. 33, no. $1,2005$.

[10] B. K. Semarang, "Senarai: inventarisasi dan dokumentasi bangunan dan kawasan pusaka budaya kota Semarang," Semarang Bappeda Pemerintah Kota Semarang, 2006.

[11] A. Y. Puspitasari and W. O. S. K. Ramli, "Masalah Dalam Pengelolaan Kota Lama Semarang Sebagai Nominasi Situs Warisan Dunia,” J. Planol., vol. 15, no. 1, pp. 96$114,2018$. 
